\title{
ESTIMATE OF DENITRIFYING MICROBIOTA IN TERTIARY SEWAGE TREATMENT AND KINETICS OF THE DENITRIFICATION PROCESS USING DIFFERENT SOURCES OF CARBON
}

\author{
Margarida Marchetto*; Eloisa Pozzi Gianotti; José Roberto Campos; Roberto Cleto Pires; \\ Elizabeth de Mattos Moraes
}

Departamento de Hidráulica e Saneamento, Escola de Engenharia de São Carlos, Universidade de São Paulo.

Submitted: November 29, 2001; Returned to authors for corrections: September 04, 2002; Approved: February 26, 2003

\begin{abstract}
A study of the kinetics of denitrification was carried out in the laboratory based on the quantification of $\mathrm{N}_{2} \mathrm{O}$, the final product of the activity of denitrifying microorganisms, when the enzymatic reduction of $\mathrm{N}_{2} \mathrm{O}$ to $\mathrm{N}_{2}$ was blocked by acetylene. Concentrated mixed liquor (sludge from a reactor with intermittent aeration used for sewage treatment) was used as the inoculum, while methanol, acetic acid, glucose, effluent sewage from an anaerobic fluidized bed reactor and synthetic substrate simulating domestic sewage were used as carbon sources. The mean concentration of nitrate was $20 \mathrm{mg} / \mathrm{L}$. Maxima of $\mathrm{N}_{2} \mathrm{O}$ production and $\mathrm{NO}_{3}{ }^{-}$consumption occurred between $0.5 \mathrm{~h}$ and $2.0 \mathrm{~h}$ of incubation using all the carbon sources, which characterized the denitrification process. Acetic acid and methanol were responsible for the highest rates of $\mathrm{N}_{2} \mathrm{O}$ production. The estimated number of denitrifying microorganisms in the reactor with intermittent aeration, using the MPN technique, varied from $10^{9}$ to $10^{10} \mathrm{MPN} / \mathrm{g} \mathrm{VSS}$, indicating a high potential for the occurrence of denitrification.
\end{abstract}

Key words: denitrifying activity, denitrifying bacteria, denitrification, tertiary treatment of domestic sewage

\section{INTRODUCTION}

Optimization of nitrogen removal in biological reactors has been persistently pursued in recent years, aiming particularly at reducing the cost of building and operating treatment plants, as well as to fit effluents to the standards of emission and quality required by law. Owing to the costs, outside sources of carbon used in pioneer nutrient removal projects are being replaced by internal sources, such as the waste itself, induced storage, and endogenous respiration of sludge (26).

Denitrification is an important reaction in sewage treatment for the biological removal of nitrogen from residual waters that improves the quality of the effluent eliminating one of the eutrophication factors of the recipient body of water. Rittman and Langeland (21), Campos (5), Metcalf and Eddy (17), and van Haandel and Lettinga (30) state that the use of the biological denitrification process together with denitrification in the treatment plant offers several advantages, such as (a) oxygen savings (the organic material can be stabilized in the absence of oxygen), with a resulting reduction in energy requirements; (b) consumption and generation of alkalinity and increased buffer capacity of the medium; (c) potential elimination of the need for an exogenous source of carbon. Satoh and Matoso (22) and Sasaki et al. (23) point out that the high rate of nitrogen removal may be one of the main characteristics of the intermittent aeration process. In addition to oxidized nitrogen compounds, the reactions involved in the denitrification process in intermittently aerated reactors (aerobic/anoxic) consume rapidly and slowly biodegradable organic matter (31). Knowledge of the kinetics of the denitrifying activity can be obtained by determination of the maximum denitrification rate when other carbon sources are available besides those present in domestic sewage when corroborated by the estimated MPN of denitrifying microorganisms. This knowledge may serve as an important guideline for the implementation of post-treatment processes for anaerobic reactor effluents.

\footnotetext{
* Corresponding author. Mailing address: Departamento de Hidráulica e Saneamento, EESC-Escola de Engenharia de São Carlos, USP - Universidade de São Paulo. Av. Trabalhador San-Carlense, 400, 13566-570. São Carlos, SP, Brasil.
} 


\section{MATERIALS AND METHODS}

This study was carried out on a pilot scale in a stainless steel aerobic reactor with an effective volume of $0.082 \mathrm{~m}^{3}(0.25$ $\mathrm{m}$ wide, $0.82 \mathrm{~m}$ long and $0.5 \mathrm{~m}$ high). It was aerated intermittently and fed with effluent from an anaerobic fluidized bed reactor (AFBR) treating domestic sewage. A flotation unit was built at the outlet of the aerobic reactor. Intermittent aeration took place in the aeration chamber, while flotation of the aerobic sludge occurred in the flotation chamber, with recirculation to the aeration chamber. The anaerobic reactor (AFBR), with biomass adhering to activated carbon as the supporting medium, had the following features: capacity of $32 \mathrm{~m}^{3}$, mean affluent flow of $10 \mathrm{~m}^{3} \cdot \mathrm{h}^{-1}$, operated with a mean hydraulic detention time $(\theta \mathrm{h})$ of $3.2 \mathrm{~h}$ and average temperature of $26 \pm 2^{\circ} \mathrm{C}$.

Different aeration/non-aeration cycle times were tested in the reactor with intermittent aeration and suspended biomass: cycles of $150 \mathrm{~min} / 120 \mathrm{~min}$ and of $120 \mathrm{~min} / 240 \mathrm{~min}$, during which the kinetic denitrification tests were carried out. The dissolved oxygen (DO), which was monitored daily, reached maximum concentrations of $4 \mathrm{mg} / \mathrm{L}$ at a ambient temperature of $25 \pm 2^{\circ} \mathrm{C}$. Removal of $\mathrm{BOD}_{5}$ (Biochemical Oxygen Demand) and COD (Chemical Oxygen Demand), nitrification, and denitrification occurred under these conditions. The flotation unit, coupled to the aerobic reactor, received the effluent and separated the phases (clarification). The organic carbon (mean COD of 180 $\mathrm{mg} / \mathrm{L}$ ) remaining in the fluidized bed reactor was used by the denitrifying microorganisms.

The denitrifying microbiota was estimated using hydraulic detention times $(\theta \mathrm{h})$ of $8 \mathrm{~h}$ (with the two above-mentioned aeration cycles) and $6 \mathrm{~h}$ (with 2-h aeration and non-aeration cycles). This estimate was performed by the Most Probable Number (MPN) technique modified by Tiedje (27) and adapted to fluid samples (mixed liquor). Five tubes with replicate sample volumes with decimal dilutions were incubated under anaerobic conditions, during 15 days at $30^{\circ} \mathrm{C} \pm 1^{\circ} \mathrm{C}$, in a selective medium, Nutrient Broth ("Difco") in a $5 \mathrm{mM}$ solution of $\mathrm{NaNO}_{3}$. The result was expressed in MPN per gram of volatile suspended solids (VSS).

The kinetic test, which was performed to estimate the activity of the denitrifying microorganisms, simulated the conditions of the reactor, operated with a mean OLR (organic loading rate) of $0.61 \mathrm{kgCOD} / \mathrm{m}^{3}$.day. The following sources of carbon (carbon measured as COD) were used as substrates: methanol, acetic acid, glucose, domestic sewage (effluent from the anaerobic reactor), and synthetic substrate simulating domestic sewage (28). The concentration of nitrate was kept at an average of $20 \mathrm{mg}$ $\mathrm{NO}_{3}-\mathrm{N} / \mathrm{L}$ and the total volatile solids (TVS) around $4000 \mathrm{mg} / \mathrm{L}$.

The kinetic study of the denitrification process was carried out based on the quantification of $\mathrm{N}_{2} \mathrm{O}$, the final product of denitrifying microorganism activity, using acetylene as a blocker of the enzymatic reduction of $\mathrm{N}_{2} \mathrm{O}$ to $\mathrm{N}_{2}$ (32). In this study, the samples were kept in $400 \mathrm{~mL}$ reactors containing $300 \mathrm{~mL}$ of reactive material (organic substrate, macro and micronutrients, sludge and nitrate) and $100 \mathrm{~mL}$ of gaseous phase. Following a 5min flow of $\mathrm{N}_{2}$ to establish anoxic condition, each reactor was sealed with a rubber plug, after which $10 \%$ of the gaseous phase was replaced by acetylene at a partial pressure of $10 \mathrm{kPa}$ and the containers were incubated in the dark, under shaking and controlled temperature $\left(30^{\circ} \mathrm{C} \pm 1^{\circ} \mathrm{C}\right)$. The accumulated concentration of $\mathrm{N}_{2} \mathrm{O}$ in the reactors was quantified by gas chromatography, using a Gow Mac, series 150 chromatograph equipped with a thermal conductivity detector and a 2-m long "Poropack Q" (80-100 mesh) column with a $1 / 4$ " internal diameter. Hydrogen $(60 \mathrm{~mL} / \mathrm{min})$ was used as carrier gas with the oven set at a constant temperature of $40^{\circ} \mathrm{C}$. The chromatograph was coupled to an HP 3396 integrating processor. Volumes of the biogas $(500 \mu \mathrm{L})$ were injected using a gas-tight (Hamilton) syringe. The accumulated concentrations of $\mathrm{N}_{2} \mathrm{O}$ in the reactors were calculated based on Tiedje's (27) equation. The experimental results were adjusted using Boltzman's function (sigmoidal) and the maximum specific gas production rates $\left(\mathrm{R}_{\max }\right)$ were calculated based on the derivative of the adjusted curve.

The monitored parameters of the affluent and effluent of the anaerobic fluidized bed reactor (AFBR) that fed the reactor with intermittent aeration $(\theta \mathrm{h}$ of $6 \mathrm{~h})$ and its effluent were $\mathrm{pH}$, temperature, total phosphate $\left(\mathrm{PO}_{4}\right), \mathrm{COD}$, alkalinity to bicarbonate, total volatile acids, $\mathrm{N}$-Kjeldhal, ammonia, nitrite, nitrate and VSS. Measurements were taken of the initial concentrations of nitrate and of COD maintained in the reactors (batches, with the different carbon sources), as well as their removal efficiencies. The tests were made using sludge from the reactor with an $\theta \mathrm{h}$ of $8 \mathrm{~h}$ and intermittent aeration with $2 \mathrm{~h}$ aeration and $4 \mathrm{~h}$ non-aeration cycles.

These measurements and identifications were based on the recommendations of the Standard Methods for the Examination of Water and Wastewater (1995). The concentrations of volatile acids in the effluent from the anaerobic reactor (AFBR) were quantified to identify the types of carbon for the denitrifying microorganisms, using gas chromatography, according to Moraes et al. (19).

\section{RESULTS AND DISCUSSION}

The estimated number of denitrifying microorganisms remained at practically the same order of magnitude throughout the monitoring period of the reactor. As shown in Table 1, the MPN/g VSS remained stable during each of the cycles under study, with averages in the order of $10^{10} \mathrm{MPN} / \mathrm{g}$ VSS (variation of $10^{9}$ to $10^{10} \mathrm{MPN} / \mathrm{g}$ VSS). These results were higher than those found by Gianotti et al. (11) in anoxic reactors fed by synthetic substrate simulating domestic sewage and nitrate, whose mean MPN values were in the order of $10^{7}$ cells/g VSS in a concentration of $10 \mathrm{mg} \mathrm{NO}^{-}-\mathrm{N} / \mathrm{L}$, and of $10^{9}$ cells/g VSS, in a concentration of $50 \mathrm{mg} \mathrm{NO}_{3}^{-}-\mathrm{N} / \mathrm{L}$. 
Table 1. Estimated number of denitrifying microorganisms in the intermittent aeration reactor, with $\theta \mathrm{h}$ of $8 \mathrm{~h}$ and $6 \mathrm{~h}$.

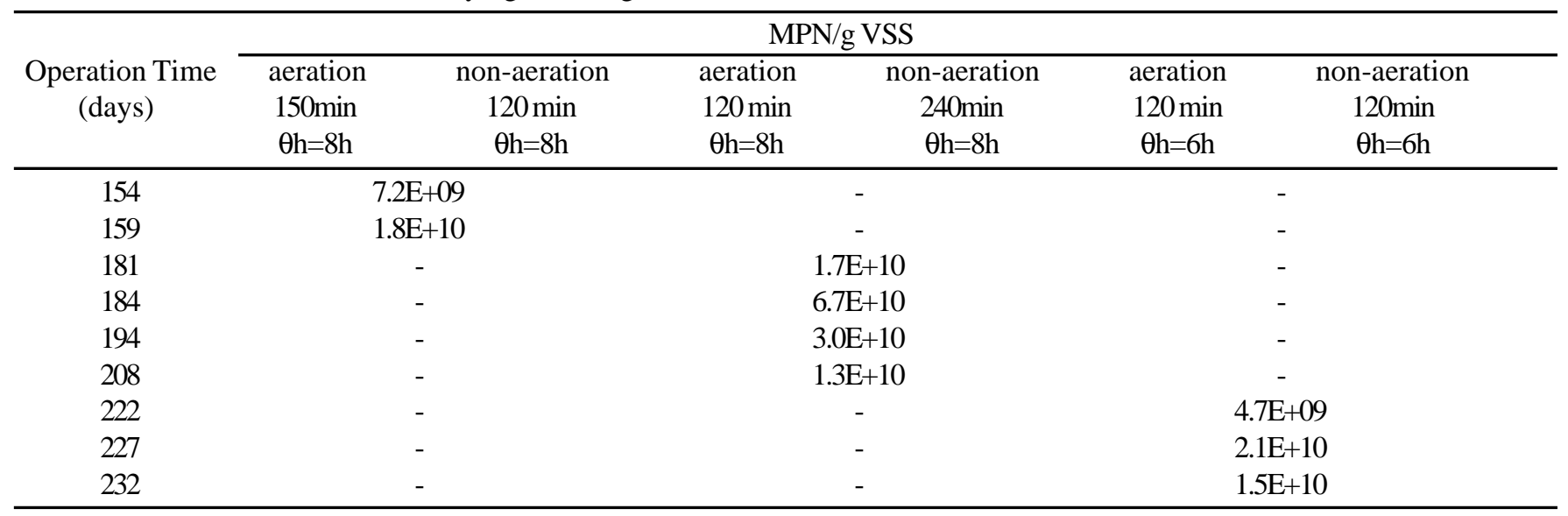

Marchetto et al. (15), in a laboratory scale study using two serial reactors to treat domestic sewage - a compartmented anaerobic reactor and a microaerated reactor - operated with low concentrations of dissolved oxygen (DO between $0.20 \mathrm{mg}$ / $\mathrm{L}$ and $0.90 \mathrm{mg} / \mathrm{L}$ ), found mean MPN values of denitrifying microorganisms of $4.9 .10^{8}$ cells/g VSS ( $\theta \mathrm{h}$ of $8 \mathrm{~h}$ ) and of 2.5.10 $0^{8} \mathrm{cells} / \mathrm{g}$ VSS ( $\theta \mathrm{h}$ of $\left.14 \mathrm{~h}\right)$.

In this study, MPN per volume of reactive material (mixed liquor) was estimated to be of the order of $10^{6}$ to $10^{7} \mathrm{MPN} / \mathrm{mL}$, a variation also observed by Etchebehere et al. (8) in sludge samples from a denitrifying reactor treating percolated sanitary landfill material.

The high values of MPN of denitrifying microorganisms may be associated with the diversified composition of remanent electron donors after treatment in the anaerobic fluidized bed reactor, which fed the intermittently aerated reactor. Moreover, the diversified metabolism of these microorganisms, associated with the contributing denitrification factors such as the presence of nitrate in the intermittent aeration reactor, the low concentration of DO during the periods of non-aeration, and the environmental conditions (temperature and $\mathrm{pH}$ ), may also have favored the development of denitrifying microbiota. Table 2 lists the mean values of some of the monitoring parameters of the AFBR and the intermittent aeration reactor on a pilot scale, using $\theta \mathrm{h}$ of $6 \mathrm{~h}$.

The results presented in Table 2 indicate the satisfactory response of the nitrifying and denitrifying microbiota in the reactor to intermittent aeration. Nitrification (oxidation of ammonia-N to nitrite and nitrate) occurred during the aerated period in the same unit and, during the absence of aeration, the denitrifying microorganisms reduced nitrate and nitrite to molecular nitrogen. The system produced an N-Kjeldhal conversion of $72 \%$ and $84 \%$, with a $9.5 \mathrm{mg} / \mathrm{L}$ residue in the case of non-filtered effluent and of $5.5 \mathrm{mg} / \mathrm{L}$ in the filtered one. The source of electrons used in the denitrification process was solely remanent organic matter from the anaerobic reactor (AFBR), which left a residue of $8.5 \mathrm{mg} / \mathrm{L}$ of $\mathrm{NO}_{3}^{-}-\mathrm{N}$. The use of
Table2. Mean values of monitored parameters of the anaerobic fluidized bed reactor (AFBR) and the intermittent aeration reactor ( $\theta h$ of $6 h)$.

\begin{tabular}{|c|c|c|c|}
\hline \multirow[b]{2}{*}{ Parameter } & \multicolumn{3}{|c|}{ Effluent } \\
\hline & $\begin{array}{l}\text { Affluent of } \\
\text { the AFBR }\end{array}$ & AFBR & $\begin{array}{l}\text { Intermittent } \\
\text { Aeration }\end{array}$ \\
\hline $\mathrm{pH}$ & 7.3 & 7.2 & 6.9 \\
\hline $\mathrm{T}\left({ }^{\circ} \mathrm{C}\right)$ & $26 \pm 2$ & - & 25 \\
\hline $\mathrm{P}-\mathrm{PO}_{4}^{-3}(\mathrm{mg} / \mathrm{L})$ & 14.0 & 10.7 & $1.5^{*}-0.8^{* *}$ \\
\hline $\mathrm{COD}_{\mathrm{B}}(\mathrm{mg} / \mathrm{L})$ & 510 & 183 & $38^{*}-26^{* *}$ \\
\hline $\begin{array}{l}\text { Alkalinity to bicarbonate } \\
\left(\mathrm{mgCaCO}_{3} / \mathrm{L}\right)\end{array}$ & e & 70 & 45 \\
\hline $\begin{array}{l}\text { Total volatile acids } \\
\text { (mgHAc/L) }\end{array}$ & 26 & 17 & 10 \\
\hline $\mathrm{N}$ - ammonia $(\mathrm{mg} / \mathrm{L})$ & 20 & 16 & 3 \\
\hline N-Kjeldhal (mg/L) & 34 & 26 & $9.5 *-5.5 * *$ \\
\hline $\mathrm{NO}_{3}^{-}-\mathrm{N}(\mathrm{mg} / \mathrm{L})$ & 0.3 & 0.3 & 8.5 \\
\hline $\mathrm{NO}_{2}^{-}-\mathrm{N}(\mathrm{mg} / \mathrm{L})$ & $\mathrm{Nd}$ & 0.02 & 2.50 \\
\hline mgVSS/L effluent & & 33 & 12 \\
\hline
\end{tabular}

Nd - Non-detectable value; * raw sample; ** filtered sample.

endogenous carbon may increase to low denitrification the rates and limit the overall efficiency of nitrogen removal (26). COD removal rates of $95 \%$ and $92 \%$ were also found, with mean residues of $26.0 \mathrm{mg} / \mathrm{L}$ and $38.0 \mathrm{mg} / \mathrm{L}$, respectively, in the filtered and non-filtered effluent.

The denitrification rate in a reactor depends on the concentrations of nitrate, on the active biomass and on organic carbon, whose origin also plays a significant role $(13,16)$.

An adequate $\mathrm{C} / \mathrm{N}$ ratio and access to easily degradable carbon sources are essential to maintain the biochemical reactions involved in the denitrification process (20). Table 3 lists the initial and final concentrations of $\mathrm{COD}$ and $\mathrm{NO}_{3}{ }^{-} \mathrm{N}$ of these experiments, 
as well as $\mathrm{COD} / \mathrm{NO}_{3}^{-}{ }^{-} \mathrm{N}$ ratios and percentage of $\mathrm{NO}_{3}{ }^{-}-\mathrm{N}$ removal for the substrates like domestic sewage, methanol, acetic acid, glucose, and synthetic substrate simulating domestic sewage.

The purpose of this study was to identify the response of the denitrifying activity to the different carbon sources, ensuring adequate supplies of carbon and nitrogen. As can be seen in Table 3, the $\mathrm{C} / \mathrm{N}$ ratios (carbon measured as $\mathrm{COD}$ ) remained high when methanol, acetic acid and glucose were used as substrates, but were closer to the real reactor operation situation when domestic and synthetic sewage was used. Her and Huang (12) found that the denitrification efficiency increased linearly with the increase in the $\mathrm{C} / \mathrm{N}$ ratio. The lowest values of $\mathrm{C} / \mathrm{NO}_{3}{ }^{-} \mathrm{N}$ ratios in this process were 0.9 for acetic acid, 1.9 for methanol and 3.0 for benzoic acid. Above these values, the denitrification efficiency remained constant, dropping after reaching values of 5.0 for methanol, 25.0 for acetic acid and glucose, and 3.6 for benzoic acid. The endogenous denitrification efficiency varied from $9.2 \%$ to $17.8 \%$, requiring an exogenous carbon source.

In a study involving the removal of $\mathrm{NO}_{3}{ }^{-} \mathrm{N}$ from underground waters, Mohseni-Bandpi and Elliott (18) found that the best C/ $\mathrm{NO}_{3}{ }^{-} \mathrm{N}$ ratios for denitrification were 1.1 for methanol, 1.25 for ethanol and 1.7 for acetic acid.

In this study, although the quantification of the available carbon for denitrification was determined through the COD, the $\mathrm{C} / \mathrm{NO}_{3}{ }^{-} \mathrm{N}$ ratios were higher than those reported in the literature. Nitrate removal, however, was satisfactory, i.e., $94 \%$ to $96 \%$ (Table 3). The rate of the denitrification process is influenced by the nature of the carbon sources, i.e., the more easily degradable they are, the faster the process. Fig. 1, F1 to F5, illustrate the accumulated $\mathrm{N}_{2} \mathrm{O}$ production, maximum rates and specific maxima, using sludge (inoculum) from the intermittent aeration reactor after 208 days, fed with five different carbon sources: domestic sewage, synthetic substrate simulating domestic sewage, methanol, acetic acid, and glucose.

The maximum $\mathrm{N}_{2} \mathrm{O}$ production rates in $\mathrm{g} \mathrm{N} / \mathrm{g}$ TVS/day were $0.39 ; 0.36 ; 0.34 ; 0.25$ and 0.25 , respectively, for acetic acid, methanol, domestic sewage, glucose, and synthetic sewage. Jerônimo (14) found maximum $\mathrm{N}_{2} \mathrm{O}$ production rates, in $\mathrm{g} \mathrm{N} / \mathrm{g}$

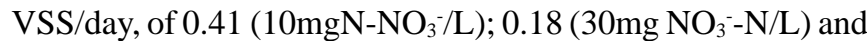
$0.19\left(50 \mathrm{mg} \mathrm{NO}_{3}^{-}-\mathrm{N} / \mathrm{L}\right)$, with the process stabilizing at $15 \mathrm{~h}, 15 \mathrm{~h}$ and $30 \mathrm{~h}$, respectively.

Acetic acid was the carbon source responsible for the highest $\mathrm{N}_{2} \mathrm{O}$ production rate, $0.39 \mathrm{gN} / \mathrm{g}$ TVS/day, while glucose and synthetic sewage were responsible for the lowest, i.e., $0.25 \mathrm{~g} \mathrm{~N} / \mathrm{g}$ TVS/day. Gerber et al. (9) also found that the rate of the denitrification process intermediated by acetic acid was higher than that of methanol and ethanol. Anderson and Rosen (2)

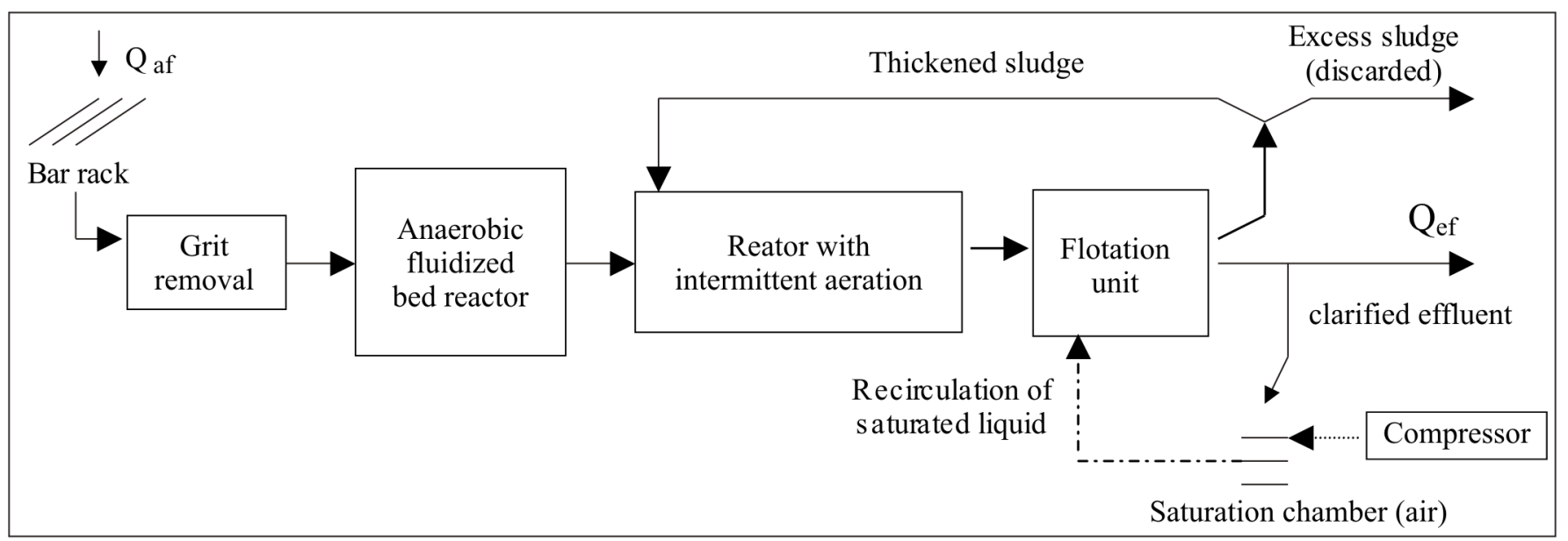

Figure 1. General view of the system used to treat domestic sewage. 

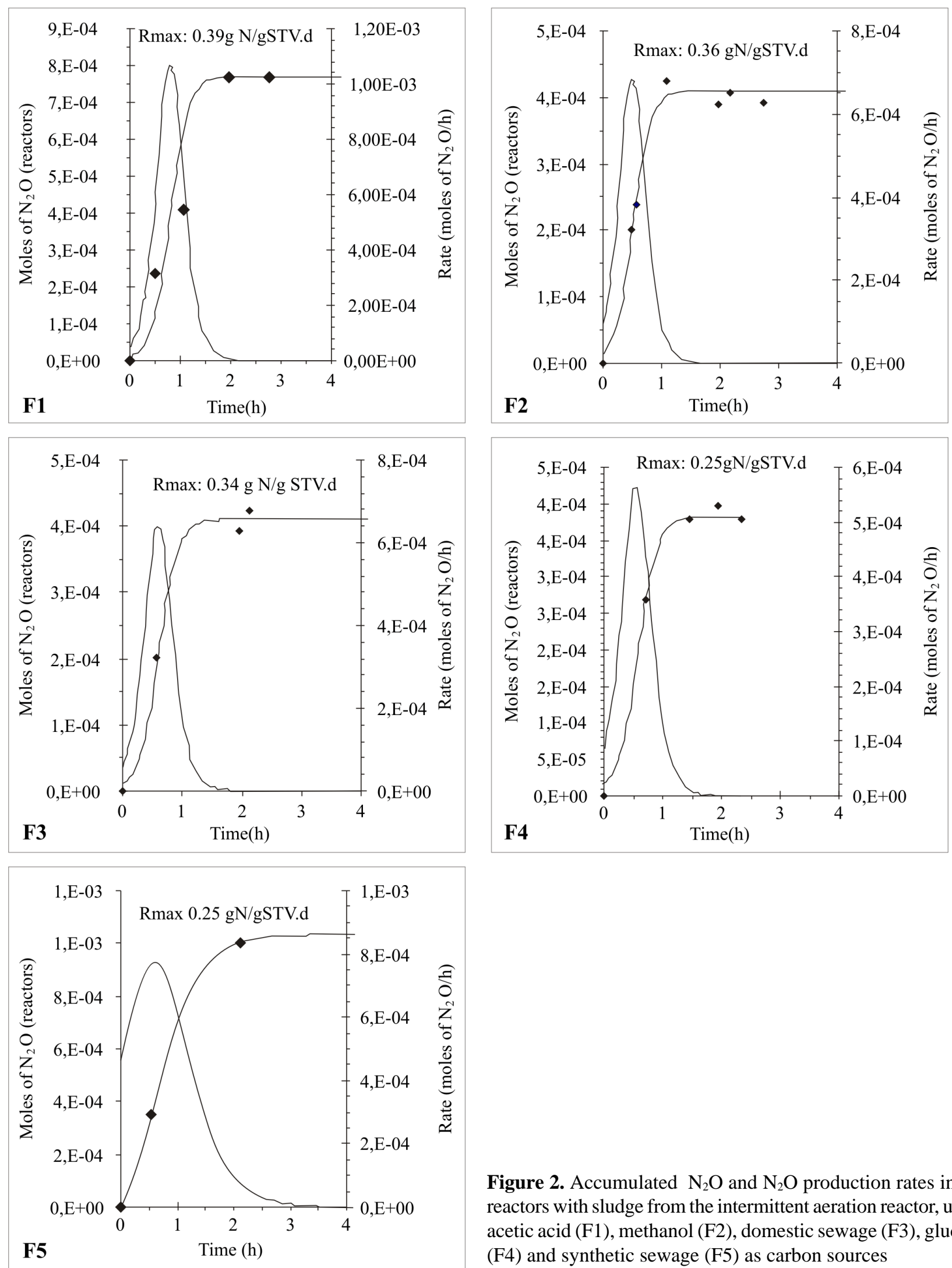

Figure 2. Accumulated $\mathrm{N}_{2} \mathrm{O}$ and $\mathrm{N}_{2} \mathrm{O}$ production rates in the reactors with sludge from the intermittent aeration reactor, using acetic acid (F1), methanol (F2), domestic sewage (F3), glucose (F4) and synthetic sewage (F5) as carbon sources 
reported that acetic acid accelerated the denitrification process in comparison to hydrolyzed starch and methanol. Carley and Mavinic (6) also found that acetate was the most efficient substrate for denitrification, followed by methanol. Tam et al. (2) reached nitrate removal efficiencies in the order of $91 \%-96 \%$, $86 \%$ and $78 \%$ using acetate, methanol and glucose, respectively. In our study, considering the five sources of carbon under study, the percentages of nitrate removal were similar (Table 3). However, the use of acetic acid produced the fastest denitrification and glucose and synthetic sewage the slowest one.

The high nitrate removal efficiency of acetic acid may be due to the favorable values of the energetic balance of the formation and degradation of the compounds involved in the process.

Mohseni-Bandpi and Elliot (18) suggest that the denitrification efficiency is significantly affected by the nature and molecular mass of carbon compounds. Denitrification was slower in the reactors fed with domestic sewage and glucose. The complexity of these substrates may have decelerated the process. In this study, the high concentration of acetic acid (high $\mathrm{C} / \mathrm{N}$ ratio) may have favored the activity of denitrifying microbiota adapted to this substrate, since the sludge used in these laboratory scale tests received effluent from an anaerobic fluidized bed reactor whose main acid component was acetic. In a sequential batch reactor (SBR) fed with anaerobically fermented reactor effluent, Rodriguez et al. (1998) found $223 \pm 24 \mathrm{mg} / \mathrm{L}$ mean concentrations of volatile fatty acids in the effluent, of which $23 \%$ consisted of acetic, $25 \%$ of propionic, and $12 \%$ of butyric acid.

\section{CONCLUSIONS}

The most probable number of denitrifying microorganisms varied from $10^{9}$ to $10^{10} \mathrm{MPN} / \mathrm{g}$ VSS.

With regard to the duration of the denitrification process, the production of $\mathrm{N}_{2} \mathrm{O}$ stabilized between $0.5 \mathrm{~h}$ and $2 \mathrm{~h}$ with the five substrates under study.

For batch reactors fed with acetate and methanol yielded the highest $\mathrm{N}_{2} \mathrm{O}$ production rates, followed by those fed with domestic sewage (effluent sewage from an anaerobic reactor), synthetic substrate simulating domestic sewage and glucose. These responses were possibly associated with the substrates' complexity.

Acetate yielded the highest $\mathrm{N}_{2} \mathrm{O}$ production rate, suggesting adaptation of the denitrifying microbiota to this substrate, since the intermittent aeration reactor was fed with effluent from the anaerobic fluidized bed reactor.

\section{ACKNOWLEDGEMENTS}

The authors gratefully acknowledge the financial support of PRONEX (Program of Support for Nucleuses of Excellence) and PROSAB (Program of Basic Sanitation) for this study.

\section{RESUMO}

\section{Estimativa da microbiota desnitrificante em tratamento terciário de esgoto sanitário e cinética do processo de desnitrificação com diferentes fontes de carbono}

$\mathrm{O}$ estudo da cinética do processo de desnitrificação foi realizado em laboratório a partir da quantificação de $\mathrm{N}_{2} \mathrm{O}$, produto final da atividade de organismos desnitrificantes, quando acetileno bloqueou a redução enzimática de $\mathrm{N}_{2} \mathrm{O}$ para $\mathrm{N}_{2}$. Foram utilizados, como inóculo, licor misto concentrado (lodo proveniente de reator com aeração intermitente tratando esgoto sanitário) e, como fontes de carbono: metanol, ácido acético, glicose, esgoto efluente de reator anaeróbio de leito expandido/ fluidificado e substrato sintético simulando esgoto sanitário. A concentração média de nitrato foi de $20 \mathrm{mg} / \mathrm{L}$. Entre $0,5 \mathrm{~h}$ e 2,0h de incubação, ocorreram máximos de produção de $\mathrm{N}_{2} \mathrm{O}$ e de consumo de $\mathrm{NO}_{3}{ }^{-}$, com todas as fontes de carbono usadas, caracterizando o processo de desnitrificação. Ácido acético e metanol foram responsáveis pelas maiores velocidades de produção de $\mathrm{N}_{2} \mathrm{O}$. Os números estimados de microrganismos desnitrificantes no reator com aeração intermitente, empregando a técnica de NMP, variaram entre $10^{9}$ a $10^{10} \mathrm{NMP} / \mathrm{g} . \mathrm{SSV}$, indicando elevado potencial para a ocorrência da desnitrificação.

Palavras-chave: atividade desnitrificante, bactérias desnitrificantes, desnitrificação, tratamento terciário de esgoto sanitário

\section{REFERENCES}

1. Awwa-Apha, W.P.C.F. Standard Methods for the Examination of Water and Wastewater. 20th Edition, New York, 2000.

2. Anderson, B. and Rosen, B. Upgrading for Biological Nitrogen Removal - Some Full-Scale Experience from Sweden. Wat. Sci. Tech., 22(7-8): 93-104, 1990.

3. Aesoy, A.; Odegaard, H. Nitrogen Removal Efficiency and Capacity in Biofilms with Biologically Hydrolised Sludge as a Carbonn Source. Wat. Sci Tech., 30(6): 63-71, 1994.

4. Abeling, U.; Seyfried, C.F. Anaerobic-Aerobic Treatment of HighStrength Ammonium Wastewater-Nitrogen Memoval via Nitrite. Wat. Sci. Tech., 26(516): 1007-1015, 1992.

5. Campos, J.R. Remoção de DQO e de Nitrogênio em um Sistema de três Reatores Biológicos de Filme Fixo em Série. 295p., 1989. Tese de Livre Docência - Escola de Engenharia de São Carlos-USP.

6. Carley, B.N.; Mavinic, D.S. The Effects of External Carbon Loading on Nitrification and Denitrification of a High-Ammonia Landfill Leachate. Jour. Wat. Pollut. Control Fed., 63(1): 51-59, 1991.

7. Eilersen, A.M.; Henze, M.; Kloft, L. Effect of Volatile Fatty Acids and Trimethylamine on Denitrification in Activated Sludge. Wat. Res., 29(5): 1259-1266, 1995.

8. Etchebehere, C. et al. Characterization of Microflora of a Denitrifying Reactor by Standard Culture Dependent Techniques and New Molecular Culture-Independent Tools. Anais da VI Oficina e Seminário Latino-Ameriacno de Digestão Anaeróbia. Recife-PE, Brasil, (1): 143-149, 2000.

9. Gerber, A.; Villiers R.H.; Mostert E.S.; Riet C.J.J. The Phenomenon of Simultaneous Phosphate Uptake and Release, and its Importance 
in Biological Nutrient Removal, In: Biological Phosphate Removal from Wastewaters, Edited by Ramadori R., Pergamon Press, Oxford, 1987, p. 123-134.

10. Germán et. al. Wastewater Fermentation and Nutrient Removal in Sequencing Batch Reactors. Wat. Sci. Tech., 38(1): 255-264, 1998.

11. Gianotti, E.P.; Jerônimo, V.L.; Campos, J.R. Estimation of the Number of Denitrifying Bacteria and Maximum rate of Denitrification in Anoxic Reactor. Revista Microbiol., 28(suppl 1): 91-94, 1997.

12. Her J.J.; Huang J.S. Influence of Carbon Source and C/N Ratio on Nitrate/nitrite Denitrification and Carbon Breakthrough. Bioresource Technology, 54: 45-51, 1995.

13. Isaacs, S.H.; Henze, M. Controlled carbon source addition to na alternating nitrification-denitrification wastewater treatment process including biological P removal. Water Research, 29(61): 77-89, 1995.

14. Jerônimo V.L. Uso do Nitrato como Receptor de Elétrons no Tratamento de Esgoto Sanitário em Reator Anóxico. São Carlos, SP, EESC-USP, Dissertação (Mestrado), 1998.

15. Marchetto, M.; Gianotti, E.P.; Campos, J.R. Estimativa do Número de Microrganismos Desnitrificantes em Reator Microaerofílico Utilizando Efluente de Reator Anaeróbio Tratando Esgoto Doméstico. XX Congresso Brasileiro de Microbiologia. SalvadorBA. Brasil, 1999.

16. Mehlhart, G.F. Upgrading of existing tricking filter plantas for denitrification. Wat. Sci. Tech., 30(6): 173-179, 1994.

17. Metcalf and Eddy. Wastewater Engineering: Treatment, Disposal and Reuse $3^{\mathrm{a}}$ ed. United States, Mc Graw-Hill 1991, 1334 p.

18. Mohseni-Bandpi, A.; Elliott, D.J. Groundwater Denitrification With Alternative Carbon Sources Wat. Sci. Tech., 38(6): 237-243, 1998.

19. Moraes et al. Determinação da Alcalinidade Real em Efluentes de Reatores Anaeróbios por Titulação Condutométrica. Anais da VI Oficina e Seminário Latino-Americano de Digestão Anaeróbia. Recife-PE, Brasil. Vol. II, 2000, p. 231-234.

20. Plaza, E.; Bosander, J.; Trela, J. Factors Effeting Biological Nitrogen Removal Efficiency in a Large Wastewater Treatment Plant.
Advanced Wastewater Treatment and Reclamation Water Science and Technology, 24(7): 121-131, 1991.

21. Rittmann, B.E.; Langeland, W.E. Simultaneous Denitrification with Nitrification in Single-Channel Oxidation Ditches. Journal WPCF, 57(4): 300-308, 1985.

22. Satoh, H.M.; Matoso, T. Deterioration of Enhanced Biological Phosphorus Removal by Domination of Microorganisms Without Polyphosphate Accumulation. Wat. Sci. Tech., 30(6): 203-211, 1994.

23. Sasaki, K.; Yamamoto, Y.; Tsumura, K.; Ouchi, S.; Mori, Y. Development of 2-Reactor Intermittent-Aeration Activated Sludge Process for Simultaneous Removal of Nitrogen and Phosphorus. Wat. Sci Tech., 34(1-2): 111-118, 1996.

24. Shound, H. et al. Denitrification by Fungi FEMS Microbial. Lett., 94: 277-282, 1992.

25. Tam, N.F.Y.; Wong, Y.S.; Leung, G. Significance of External Carbon Sources on Simultaneous Removal of Nutrients from Wastewater Wat. Sci and Tech., 26(5-6): 1047-1055, 1992.

26. Tam, N.F.Y.; Lau, P.S.; Wong, Y.S. Wastewater Inorganic $\mathrm{N}$ and $\mathrm{P}$ Removal by Immobilized Chlorella vulgaris. Wat. Sci. and Tech., 30(6): 369-374, 1994.

27. Tiedje J.M. Denitrification In: Page A.L. (ed). Methods of soil analysis. Part 2. Chemical and microbiological properties. Madison, Wisconsin: USA, 1982, p. 1011-1026.

28. Torres P. Desempenho de um Reator Anaeróbio de Manta de Lodo (UASB) de Bancada no Tratamento de Substrato Sintético Simulando Esgotos Sanitários. São Carlos-SP, EESC-USP, Dissertação (Mestrado), 1992.

29. van Haandel, A.C., Lettinga, G. Anaerobic Sewage Treatment - A Practical Guide for Regions with Hot Climate. John Wiley \& Sons, Inglaterra, 1994, 226p.

30. van Haandel, A.C.; Marais. O Comportamento do Sistema de Lodo Ativado-Teoria e Aplicação para Projeto e Operação (ed) ABES. Campina Grande, Universidade Federal da Paraiba, 1999, 448p.

31. Yoshinari, T.; Knowles, R. Acetylene Inibition of Nitrous Oxide Reduction by Denitrifying Bacteria. Biochem. Biophys. Res. Commun., 69: 705-710, 1976. 